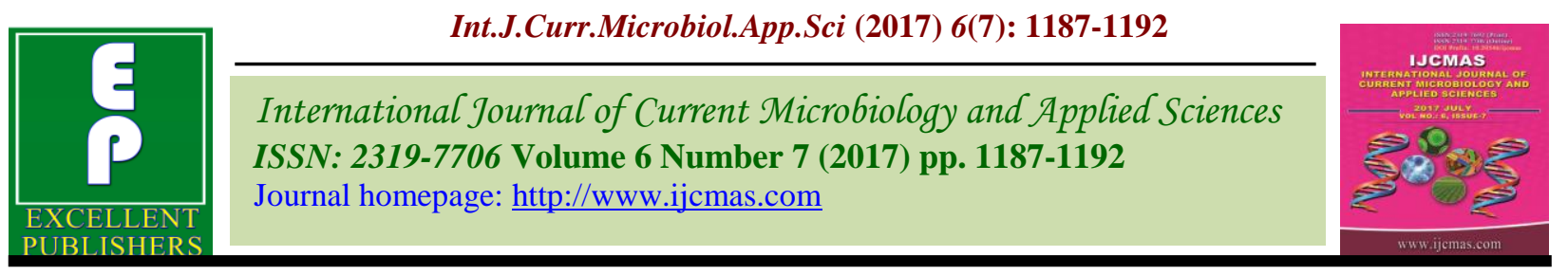

Original Research Article

https://doi.org/10.20546/ijcmas.2017.607.144

\title{
Estimation of Extent of Variability for Various Productive Traits in Sugarcane under Water-Logged Condition
}

\author{
Praveen Kumar*, Balwant Kumar and Khushboo Chandra
}

Department of Plant Breeding and Genetics, Dr. Rajendra Prasad Central Agricultural
University, Pusa-848125 (Bihar), India
*Corresponding author

\begin{tabular}{|c|c|}
\hline & A B S T R A C T \\
\hline & \multirow{9}{*}{$\begin{array}{l}\text { An investigation was carried out with the eighteen high sucrose containing } \\
\text { sugarcane clones to estimate the extent of variability for various productive traits } \\
\text { under water-logged condition. The analysis of variance revealed highly significant } \\
\text { differences among the clones for fourteen traits and significant for rest traits viz., } \\
\text { germination } \% \text { at } 45 \text { DAP, plant height at } 150 \text { days, single cane weight and purity } \\
\% \text { at } 10 \text { month stage. The Variability studies showed high estimates of GCV and } \\
\text { PCV for traits viz., length of aerial root and dry weight of aerial roots. In present } \\
\text { set of materials high heritability with high genetic advance as per cent of mean } \\
\text { was found in length of aerial root. Similarly, high heritability with moderate } \\
\text { genetic advance as percent of means was observed for plant height at } 240 \text { days, } \\
\text { height at } 360 \text { days, pol per cent at } 12 \text { month stage and single cane weight, } \\
\text { indicating the role of dominant genetic effects in determination of these characters } \\
\text { and its improvements. }\end{array}$} \\
\hline Keywords & \\
\hline $\begin{array}{l}\text { Sugarcane, Water } \\
\text { logging, }\end{array}$ & \\
\hline Variability, PCV, & \\
\hline $\begin{array}{l}\text { GCV, Heritability, } \\
\text { Genetic advance. }\end{array}$ & \\
\hline Article Info & \\
\hline $\begin{array}{l}\text { Accepted: } \\
\text { 17 June } 2017\end{array}$ & \\
\hline $\begin{array}{l}\text { Available Online: } \\
10 \text { July } 2017\end{array}$ & \\
\hline & \\
\hline
\end{tabular}

\section{Introduction}

Sugarcane is a perennial, tropical; monocotyledonous crop which is cultivated in tropical and sub- tropical region of the world primarily for its ability to store high concentration of sugar in the inter-node and propagate through stem cutting. It grows under varied soil and climatic conditions, but its productivity is generally limited by abiotic and biotic stresses, as it has to face vagaries of nature during its yearlong life in the field. National production of it is 366.80 million tones and productivity is $69.20 \mathrm{t} / \mathrm{ha}$ whereas productivity in Bihar is 50 t/ha (2014-15, Indian Sugar February, 2016). In India 10 -30 per cent of sugarcane area is affected by water logging which is one of the major constraints affecting crop productivity in the IndoGangetic belt and the coastal area about 73 per cent annual rainfall in India is received during the southwest monsoon (June to September) which is primary cause for water logging. North Bihar is main sugarcane growing tract where about 35-40 per cent of sugarcane cultivated area remains waterlogging during monsoon season which coincides with the grand growth period of the crop. In water-logged areas, cane yield generally declined by $15-20$ per cent. If the water-logging is in the early stage of crop growth it affects the germination, tillering and 
cane growth, which may result in crop failure. The knowledge of nature and extent of genetic variation available in the germplasm or breeding material helps the breeder for planning sound breeding programmes. Therefore, present investigation was formulated to Estimate the extent of variability for various productive traits under water-logging condition.

\section{Materials and Methods}

The experimental materials were high sucrose containing eighteen sugarcane clones including two checks (BO 91 and CoLk 94184) namely CoX 12164, CoX 12236, CoX 12271, CoX 12348, CoX 11506, CoX 12599, CoX 12577, CoX 12191, CoX 12024, CoX 12269, CoX 12137, CoX 12268, CoX 12356, CoX 12086, CoX 12546 and CoX12079 which were planted in Paddy block at Dr. Rajendra Prasad Central Agricultural University, Pusa, Bihar, in a Randomized Block Design with three replications during 2014 - 15 under water logging condition (water depth 45 to $60 \mathrm{~cm}$ from July to October).

Observations were record by selecting five random plants per genotype per replication for productive characters namely, germination $\%$ at 45 DAP, number of shoots at 120 DAP, plant height at 150, 240 and 360 days, cane diameter at harvest, number of millable canes, brix, pol and purity $\%$ at 10 and 12 month stage, single cane weight, number of aerial roots/ node, length of aerial root, dry weight of aerial roots during the water-logging period and cane yield.

\section{Brix $\%$ at 10 and 12 month stage}

It is a measure of total soluble solids present in the juice. It was taken directly by using a Brix hygrometer. $250 \mathrm{ml}$ juice was taken in measuring cylinder and hygrometer dip into the juice then reading was recorded from the juice level. These readings were corrected to the temperature at $20^{\circ}$ by using temperature correction chart as described by Spencer and Meade (1955).

\section{Pol \% at 10 and 12 month stage}

Pol refers to the sucrose per cent in juice. It was done according to the method described by Spencer and Meade (1955). It was estimated with the help of Polari scope. First $100 \mathrm{ml}$ juice was taken in conical flask and 4 gm Honey dry lead sub acetate was added and mixed well by shaking the flask. After few minutes this solution was filtered twice through a dry Whatsman no. 1 filter paper and the abstract was collected into a clean and dry beaker. The abstract poured into the Polari meter tube. These tubes were placed in the Polari scope. Thereafter Pol values were recorded by polarising the clear juice in Polari scope this value called dial reading. Sucrose per cent in juice was obtained by referring the brix and dial reading to Schmitz's table. Observed data for all the traits of 18 high sucrose containing sugarcane clones were assessed for statistical analysis.

\section{Results and Discussion}

Variability is measure by estimation of genotypic and phenotypic variance, genotypic and phenotypic coefficient of variation (GCV and PCV), heritability, genetic advance and genetic advance as per cent of mean. These parameters help in selection for improvement of desired characters. Environment plays an important role in the expression of phenotype. The phenotypic variability which is observable includes both genotypic (heritable) and environmental variation (non-heritable).

The analysis of variance (Table 1) showed highly significant differences for almost all the eighteen high sucrose containing clones for 14 traits in water-logging condition.This indicated that there is presence of sufficient 
variability in the material studied for waterlogging condition. The mean sum of square due to treatments was found highly significant for all the traits except germination per-cent at 45 DAP, plant height at 150 days, purity per cent at 10 month stage, purity per cent at 12 month stage under water logging condition, these traits exhibit significant differences. Thus, it implied that there is reasonably sufficient variability in material used for their study, which provides ample scope for selecting superior and desire clone by the plant breeder for further improvement. Many earlier workers Doule and Balasundaram (2003), Singh et al., (2010) reported high variability for different traits in sugarcane. To decipher the amount of existing variability in the present clones, range, mean and standard error were calculated (Table 2) However, range is the crude method of estimation of variability, which indicates observed phenotypic variability only. From the perusal of table 3 , it is observed that phenotypic variances for all the characters under study are higher than genotypic variances. This may be due to the non-genetic factor which played an important role in the manifestation of these characters. Comparatively the maximum phenotypic and genotypic variances were exhibited by the traits viz. plant height at 240 and 360 days, cane yield, number of millable canes, number of shoots at 120 DAP, plant height at (150) days, length of aerial roots, germination per cent at $45 \mathrm{DAP}$, number of aerial roots/ node. These findings were in accordance of Ravishankar et al., (2004) for cane yield/ plot and number of millable cane/ plot. The numerical value of phenotypic coefficient of variation is higher than their genotypic counterpart indicating that apparent variation is not only due to genotypes but also due to influence of environment. The narrow difference between PCV and GCV were recorded for most of the traits.

Table.1 Analysis of variance for eighteen traits in high sucrose containing sugarcane clones under water-logging condition

\begin{tabular}{|c|c|c|c|c|}
\hline \multirow[t]{2}{*}{ Sl. No. } & \multirow[t]{2}{*}{ Character } & \multicolumn{3}{|c|}{ Mean sum of square } \\
\hline & & $\begin{array}{l}\text { Replication } \\
\text { (d.f.=2) }\end{array}$ & $\begin{array}{l}\text { Treatment (d.f.= } \\
\text { 17) }\end{array}$ & $\begin{array}{l}\text { Error } \\
(\text { d.f.=34) }\end{array}$ \\
\hline 1. & Germination per cent at 45 DAP & 9.10 & $27.15 *$ & 12.17 \\
\hline 2. & Number of shoots at 120 DAP $(000 /$ ha $)$ & 13.67 & $135.24 * *$ & 43.10 \\
\hline 3. & Plant height at 150 days $(\mathrm{cm})$ & 8.45 & $108.27 *$ & 43.11 \\
\hline 4. & Plant height at 240 days $(\mathrm{cm})$ & 24.18 & $1084.56^{* *}$ & 108.82 \\
\hline 5. & Plant height at 360 days $(\mathrm{cm})$ & 32.06 & $1081.03 * *$ & 106.94 \\
\hline 6. & Cane diameter at harvest $(\mathrm{cm})$ & 0.02 & $0.29 * *$ & 0.06 \\
\hline 7. & Number of millable canes $(000 /$ ha) & 67.38 & $152.36^{* *}$ & 57.88 \\
\hline 8. & Single cane weight $(\mathrm{kg})$ & 0.01 & $0.03 * *$ & 0.005 \\
\hline 9. & Brix at 10 month $(\%)$ & 0.30 & $2.08 * *$ & 0.16 \\
\hline 10 & Pol at 10 month $(\%)$ & 0.56 & $1.50 * *$ & 0.31 \\
\hline 11 & Purity at 10 month (\%) & 11.89 & $9.10^{*}$ & 4.98 \\
\hline 12. & Brix at 12 month (\%) & 0.09 & $5.46 * *$ & 0.17 \\
\hline 13. & Pol at 12 months (\%) & 0.03 & $5.37 * *$ & 0.16 \\
\hline 14. & Purity at 12 month $(\%)$ & 3.77 & $7.41 *$ & 3.72 \\
\hline 15 & Number of aerial roots/ node & 3.63 & $23.64 * *$ & 5.12 \\
\hline 16 & Length of aerial roots $(\mathrm{cm})$ & 2.57 & $87.01 * *$ & 5.53 \\
\hline 17 & Dry weight of aerial roots $(\mathrm{g})$ & 0.03 & $8.83 * *$ & 0.03 \\
\hline 18 & Cane yield $(\mathrm{t} / \mathrm{ha})$ & 73.71 & $198.32 * *$ & 56.81 \\
\hline
\end{tabular}

$*$ Significant at 5\%,** significant at 1\% DAP - Days After Planting 
Table. 2 Mean, range and coefficient of variance for eighteen characters in high sucrose containing sugarcane clones under water-logging condition

\begin{tabular}{|c|c|c|c|c|c|}
\hline \multirow[t]{2}{*}{ Sl. No. } & \multirow[t]{2}{*}{ Character } & \multirow[t]{2}{*}{ Mean \pm SEM } & \multicolumn{2}{|c|}{ Range } & \multirow[t]{2}{*}{ C.V. } \\
\hline & & & Min. & Max. & \\
\hline 1. & Germination per cent at 45 DAP & $34.40 \pm 2.01$ & 29.87 & 38.33 & 10.14 \\
\hline 2. & Number of shoots at $120 \mathrm{DAP}(000 / \mathrm{ha})$ & $125.19 \pm 3.79$ & 110.97 & 133.33 & 5.24 \\
\hline 3. & Plant height at 150 days $(\mathrm{cm})$ & $110.11 \pm 3.79$ & 100.00 & 119.67 & 5.96 \\
\hline 4. & Plant height at 240 days $(\mathrm{cm})$ & $179.86 \pm 6.02$ & 153.20 & 213.80 & 5.80 \\
\hline 5. & Plant height at 360 days $(\mathrm{cm})$ & $190.17 \pm 5.97$ & 163.67 & 223.00 & 5.44 \\
\hline 6. & Cane diameter at harvest $(\mathrm{cm})$ & $2.31 \pm 0.14$ & 1.87 & 3.20 & 10.49 \\
\hline 7. & Number of millable canes $(000 /$ ha $)$ & $82.48 \pm 4.39$ & 59.36 & 91.27 & 9.22 \\
\hline 8. & Single cane weight $(\mathrm{kg})$ & $0.83 \pm 0.04$ & 0.67 & 1.05 & 8.53 \\
\hline 9. & Brix at 10 month $(\%)$ & $18.30 \pm 0.23$ & 17.00 & 19.40 & 2.21 \\
\hline 10 & Pol at 10 month (\%) & $16.15 \pm 0.32$ & 14.90 & 17.31 & 3.46 \\
\hline 11 & Purity at 10 month (\%) & $88.27 \pm 1.29$ & 84.89 & 91.40 & 2.53 \\
\hline 12. & Brix at 12 month $(\%)$ & $18.33 \pm 0.23$ & 17.00 & 20.40 & 2.22 \\
\hline 13. & Pol at 12 months $(\%)$ & $16.13 \pm 0.23$ & 14.58 & 18.24 & 2.46 \\
\hline 14. & Purity at 12 month $(\%)$ & $87.96 \pm 1.11$ & 85.16 & 90.91 & 2.19 \\
\hline 15 & Number of aerial roots/ node & $13.30 \pm 4.35$ & 9.33 & 18.67 & 17.02 \\
\hline 16 & Length of aerial roots $(\mathrm{cm})$ & $17.46 \pm 1.30$ & 11.33 & 34.67 & 13.47 \\
\hline 17 & Dry weight of aerial roots $(\mathrm{g})$ & $2.46 \pm 1.36$ & 0.52 & 6.28 & 6.99 \\
\hline 18 & Cane yield (t/ha) & $69.51 \pm 0.10$ & 56.57 & 83.21 & 10.84 \\
\hline
\end{tabular}

Table.3 genetic parameters for eighteen characters in high sucrose containing Sugarcane clones under water-logging condition

\begin{tabular}{|l|l|c|c|c|c|c|c|}
\hline Sl. No & Characters & $\boldsymbol{\sigma}^{2} \mathbf{G}$ & $\boldsymbol{\sigma}^{2} \mathbf{P}$ & $\mathbf{G C V}$ & $\mathbf{P C V}$ & $\mathbf{h}^{\mathbf{2}}(\mathbf{b s})$ & $\mathbf{G A ~ M}$ \\
\hline $\mathbf{1 .}$ & Germination per cent at DAP & 4.99 & 17.16 & 6.50 & 12.04 & 29 & 7.22 \\
\hline $\mathbf{2 .}$ & Number of shoots at 120 DAP (000/ ha) & 30.71 & 73.81 & 4.43 & 6.86 & 42 & 5.88 \\
\hline $\mathbf{3 .}$ & Plant height at 150 days (cm) & 21.72 & 64.83 & 4.23 & 7.31 & 34 & 5.05 \\
\hline $\mathbf{4 .}$ & Plant height at 240 days (cm) & 325.25 & 434.07 & 10.03 & 11.58 & 75 & 17.88 \\
\hline $\mathbf{5 .}$ & Plant height at 360 days (cm) & 324.70 & 431.64 & 9.48 & 10.93 & 75 & 16.93 \\
\hline $\mathbf{6 .}$ & Cane diameter at harvest (cm) & 0.08 & 0.14 & 11.97 & 15.91 & 57 & 18.55 \\
\hline $\mathbf{7 .}$ & Number of millable canes (000/ ha) & 31.49 & 89.37 & 6.80 & 11.46 & 35 & 8.32 \\
\hline $\mathbf{8 .}$ & Single cane weight (kg) & 0.01 & 0.01 & 11.68 & 14.46 & 65 & 19.43 \\
\hline $\mathbf{9 .}$ & Brix at 10 month (\%) & 0.64 & 0.80 & 4.37 & 4.90 & 80 & 8.03 \\
\hline $\mathbf{1 0}$. & Pol at 10 month (\%) & 0.40 & 0.71 & 3.90 & 5.21 & 56 & 6.01 \\
\hline $\mathbf{1 1}$. & Purity at 10 month (\%) & 1.37 & 6.35 & 1.33 & 2.86 & 22 & 1.27 \\
\hline $\mathbf{1 2 .}$ & Brix at 12 month (\%) & 1.76 & 1.93 & 7.24 & 7.58 & 91 & 14.27 \\
\hline $\mathbf{1 3}$ & Pol at 12 months (\%) & 1.74 & 1.90 & 8.18 & 8.54 & 92 & 16.12 \\
\hline $\mathbf{1 4}$ & Purity at 12 month (\%) & 1.23 & 4.95 & 1.26 & 2.53 & 25 & 1.30 \\
\hline $\mathbf{1 5}$ & Number of aerial roots/ node & 6.17 & 11.29 & 18.69 & 25.28 & 55 & 28.46 \\
\hline $\mathbf{1 6}$ & Length of aerial roots (cm) & 27.16 & 32.69 & 29.85 & 32.75 & 83 & 56.05 \\
\hline $\mathbf{1 7}$ & Dry weight of aerial roots (g) & 2.93 & 4.96 & 49.21 & 64.45 & 59 & 79.42 \\
\hline $\mathbf{1 8}$ & Cane yield (t/ ha) & 47.17 & 103.98 & 9.88 & 14.67 & 45 & 13.71 \\
\hline
\end{tabular}

Among morphological characters of clones higher phenotypic and genotypic coefficient of variation were recorded for dry weight of aerial roots, length of aerial roots, number of aerial roots/ node The magnitude of phenotypic and genotypic coefficient of 
variations were moderately higher order for number of cane diameter at harvest, cane yield, single cane weight, germination per cent at 45 DAP, plant height at 240 days, number of millable canes and plant height at 360 days. The PCV and GCV of qualitative characters like brix, pol and purity per cent at 10 and 12 months were comparatively of lower magnitude. The high heritability in broad sense was recorded for pol per cent at 12 month stage, followed by brix per cent at 12 month stage, length of aerial roots, brix per cent at 10 month stage, plant height at 240 days, plant height at 360 days and single cane weight while dry weight of aerial roots, length of aerial roots and number of aerial roots/ node exhibited high genetic advance as per cent of mean.

In conclusion, High heritability coupled with high genetic advance as percent of means was observed for Length of aerial roots, suggesting the preponderance of additive genetic effect in the determination of these characters. It also indicated that selection for these characters will be effective for future improvement of clones under water logged condition. However, high heritability with moderate genetic advance as percent of means was observed Plant height at 240 days, plant height at 360 days, pol per cent at 12 month stage and single cane weight indicating the role of dominant genetic effects in determination of these characters and it require careful selection for the desired improvements in the characters.

\section{Acknowledgement}

Authors are thankful to Sugarcane Research Institute Pusa, Samastipur for providing suitable sugarcane clones for water-logged condition and all the members of Department of Genetics and Plant Breeding for their encouragement, support and providing necessary facilities.

\section{References}

Al-Sayed, H.M.; Fateh, H.S.A; Fares, W.M. (2011). Investigation on variability, broad sensed heritability and genetic advance in sugarcane (Saccharum spp.). International Journal of Agri. Science. 2(9): 839-844.

Anshuman, S., P. K. Bhatnagar., Khan, A. Q. and Shrotria, P. K. (2002). Variability and heritability. For cane yield, its components and quality characters in sugarcane (Saccharum spp complex). Indian Sug. J., 53(4): 717- 719.

Bairwa, A.K., Ram, R., Neetu, Jeena, A. S., Singh K. and Singh S. P. (2017). Estimation of the Extent of Variability for Different Morphological and Juice Quality Characters Among Early Generation Sugarcane Clones. Int.J.Curr.Microbiol.App.Sci. $\quad$ 6(2): 1272-1278.

Bhatnagar, P. K., A. Q. Khan, A. Singh and K. A. Khan (2003). Studies on genetic variability, heritability and genetic advance in plant and ratoon crops of sugarcane. Indian Sugar, 53(3): 183185.

Burton, G. W. and De Vane (1953). Estimating heritability in tall Fescue from replicated clonal material. Agron. J. 45: $475-481$

Chandrakant; Ravikant and Singh, P. K. (2007). Screening criteria for selection of superior clones in early clonal generation of Saccharum complex hybrids. Crop Improvement. 34(1): 6371.

Doule, R. B. and Balasundaram, N. (2002). Genetic variability in sugar yield and its components for selection of sugarcane. Journal of Maharashtra Agricultural Universities. 27(3): 326-327.

Falconer, D. S. (1989). Introduction to quantitative genetics. $3^{\text {rd }}$ edition Longman. New York. 
Fisher, R. A. and Yates, F. (1938). Statistical tables for Biological, Agricultural and Medical Research.

Islam, M-S; Miah, M-A-S; Begum, M-K; Alam, M-R; Arefin, M-S. (2011).Growth, yield and juice quality of some selected sugarcane clones under, water-logging stress condition.

World-Journal-of-Agricultural-Sciences. 7(4): 504-509.

Johnson, H. W., Robinson, H. F. and Comstock, R. E. (1955a). Estimates of genetic and environmental variability in soybeans. Agron. J. 47: $314-318$.

Kamat, D. N. and Singh, J. R. P. (2001). Variability in sugarcane under rainfed condition. Sugar

Tech. 3 (1): (1\&2): 65-67.

Khalid, M.; Rahman, H.; Rabban, A.; Farahatullah and Khan (2014). Qualitative and quantitative assessment of newly selected sugarcane Sarhad J. Agric. Vol. 30, No. 2.

Kumar, R. and Singh, J. R. P. (1999). Variability in sugarcane under waterlogged condition. Journal of Applied Biology. 9(2): 140-142.

Nair, N. V. and Somarajan, K. G. and Balasundaram, N. (1980). Genetic variability, heritability and genetic advance in $S$. officinarum $\mathrm{L}$. Inter. Sugar. J. 82(981): 275-276.

Panse, V. G. and Sukhatme, P. V. (1967). Statistical methods of agricultural workers $2^{\text {nd }}$ edn. pp. 381, ICAR, Publication, New Delhi.

Puneet Jain., Rishi Pal., Saini, M. L. and
Lajpat Rai. (2001). Variability, heritability and genetic advance for yield attributes in sugarcane. Indian Sugar. 51(5): 321-324.

Singh, M. K., Pandey, S. S., Kumar, R. and Singh, A. K. (2010). Estimation of genetic variability, heritability and genetic advance in mid-late maturing clones of sugarcane. Environment and Ecology. 28(4): 2301-2305.

Rahman, M. M. and Bhuiyan, M. S. R. (2009). Variability, heritability and genetic advanced for cane yield and its components in some indigenous and exotic promising clones of sugarcane (Saccharum officinarum L). Indian Sugar. 59(2): 35-42.

Sabitha, N.; Rao, K. P.; Rao, C. P. and Rao, M. S. (2007). Genetic variation, heritability and genetic advance for yield components in sugarcane. Sugar Tech. 9(4): 290-292

Spencer, G.L. and Meade,G.P.1955.Cane Sugar Hand Book. J. Wiley and Sons, N.Y.

Thippeswamy, S.; Kajjidoni, S. T.; Salimath, P. M.; Goud, J. V. and Chetti, M. B. (2001). Variability, heritability and genetic advance for cane yield and its components in sugarcane. Karnataka $J$. of Agri. Sci. 14(1): 30-34.

Tyagi, V.K.; Sharma, Satish and Bhardwaj, S. B. (2011). A study on the nature and magnitude of variations in different traits in sugarcane. Electronic Journal of Plant Breeding. 2(3): 334-341.

\section{How to cite this article:}

Praveen Kumar, Balwant Kumar and Khushboo Chandra. 2017. Estimation of Extent of Variability for Various Productive Traits in Sugarcane under Water-Logged Condition. Int.J.Curr.Microbiol.App.Sci. 6(7): 1187-1192. doi: https://doi.org/10.20546/ijcmas.2017.607.144 